\title{
Parkinson's disease and the welding job: are both related?
}

\author{
Iqbal Mochtar* and Muchtaruddin Mansyur**
}

\begin{abstract}
Up to the present, there has been a controversy on the relationship between Parkinson's disease and the welding job. The aim of this study was to obtain evidence-based information regarding the relationship between Parkinson's disease and the welding job through an evidence-based case report derived from a literature review. The review was conducted through a method of search and selection of articles in the Pubmed, Cochrane Library and JSTOR databases aimed at answering the study question. The process of searching articles used the keywords "Welding" OR "Welder" AND "Parkinson". Article selection was performed using the defined inclusion and exclusion criteria. At the initial search, 117 articles were retrieved from the three databases. Following the selection process, three articles remained, which consisted of one systematic review and two observational studies. Comparing the selected articles, the systematic review of Mortimer et al. is more relevant and appropriate for answering the clinical question. Mortimer et al. used a meta-analytical method, applied strict inclusion and exclusion criteria and excluded studies that potentially led to bias effects, lack of validity or inadequate statistical methods. Based on the selected evidence-based resources, Parkinson's disease is not related to the welding job. The welding job, however, may produce clinical symptoms and signs resembling Parkinson's disease, known as manganism.
\end{abstract}

Keywords: Welding; Parkinson's disease; evidence-based; case report
*Division of Occupational Medicine, Department of Community Medicine, Universitas Indonesia, Indonesia **Department of Community Medicine, Universitas Indonesia, Indonesia

\section{Correspondence:}

Iqbal Mochtar

Division of Occupational Medicine, Department of Community Medicine, Universitas Indonesia, Indonesia Phone: 0974-66554913

Email:muhammad.mochtar03@alumni. imperial.ac.uk

ORCID ID: 0000-0002-1057-3916

Date of first submission, June 7, 2019

Date of final revised submission,

March 8, 2020

Date of acceptance, March 16, 2020

This open access article is distributed under a Creative Commons Attribution-Non Commercial-Share Alike 4.0 International License

Cite this article as: Mochtar I, Mansyur M. Parkinson's disease and the welding job: are both related?. Univ Med 2020; 39:63-70. doi: 10.18051/UnivMed. 2020.v39.63-70 


\section{INTRODUCTION}

Parkinson's disease (PD) is the second most common neurodegenerative disease affecting 6.1 million people worldwide in 2016. ${ }^{(1)}$ The pathological basis of the disease is related to the aggregation of the alpha-synuclein protein of Lewy bodies and the loss of pigmented melanin in the midbrain, leading to the degeneration of dopaminergic neurons in the substantia nigra and dopamine insufficiency in the striatum. ${ }^{(2)}$ It is the most common cause of parkinsonism, a syndrome characterized by postural instability, tremor, bradykinesia and rigidity. ${ }^{(3)}$

Pesticide exposure, dairy product consumption, and brain trauma have been associated with an increased risk of $\mathrm{PD}$, while smoking, caffeine intake and exercise have been linked with reduced risk of the disease. ${ }^{(4,5)}$ Some studies linked PD with the welding job, due to manganese exposure in the welding works. Those studies identified neuropsychomotor symptoms and manganese deposition on MRI in manganese-exposed workers. Other studies refuted the finding and argued that PD was not related to welding works. It still remains controversial whether welders have an increased risk of PD and whether the neuropsychomotor symptoms observed in manganese-exposed workers are related to PD. ${ }^{(6)}$

The aim of this evidence-based case report was to obtain evidence-based information regarding the relationship between Parkinson's disease and the welding job through an evidencebased case report derived from a literature review.

\section{Case Illustration}

A 55-year-old male Qatari patient came with resting tremor in both hands, rigid movement, slow and unstable gait since two years ago. Due to the symptoms, he had difficulty in doing work and daily activities. The initial symptom was only tremor in the left hand, which was mild in quality and on-off. Later, the tremor occurred in both hands and was more severe and frequent. His general movement was bradykinesia without slurred speech. He was a non-smoker and had controlled diabetes and hypertension. He had been working as a welding inspector in an oil and gas company for the last 12 years. Previously, he worked as a welding technician for 8 years. His latest work was to supervise welding activities, to test welding materials, to inspect and control welding equipment and consumables such as filler wire, fluxes and electrodes. He had undergone treatment in some hospitals, including one in Germany.

The final diagnosis was idiopathic PD and he had been given some medications, including co-beneldopa and co-careldopa. Following several months of treatment, the worker observed some improvement in his symptoms. The worker believed that his condition was due to his job and therefore he planned to claim financial compensation. The clinical question for this case was: in the workers, is the welding job, compared to the non-welding jobs, associated with PD?

\section{Evidence}

Following the search of articles using the keywords (Table 1), the selection was performed using the inclusion and exclusion criteria (Figure 1). The inclusion criteria included human studies, publications within the last 10 years, in the English language, using adult subjects, and relevant to the clinical question. Exclusion criteria included pathophysiological, pharmacological and radiological studies as well as opinion papers. Applying the inclusion and exclusion criteria, the article list was shortened, and eventually only three articles remained for appraisal, consisting of one systematic review (Mortimer et al. ${ }^{(9)}$ ) and two observational studies (Racette et al. ${ }^{(10)}$ and Racette et al. ${ }^{(11)}$

The selected articles were critically appraised using the appraisal tools for a systematic review ${ }^{(7)}$ and for cross-sectional and 


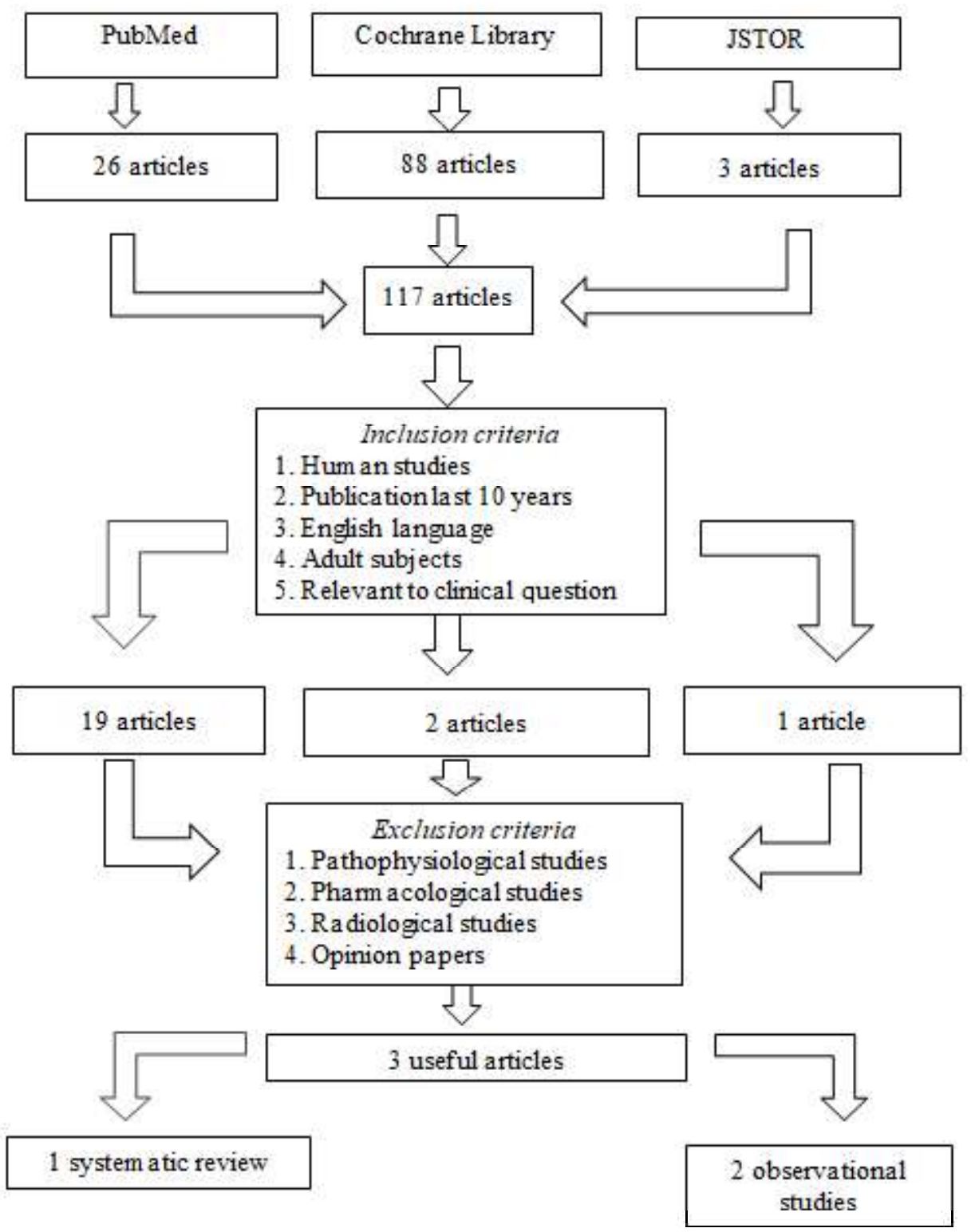

Figure 1. The process of article selection

prospective cohort studies. ${ }^{(8)}$ The results of the appraisal are presented in Tables 2, 3 and 4.

Mortimer et al. ${ }^{(9)}$ performed a meta-analysis and scrutinized 105 studies to seek the association of the welding job and manganese exposure with PD. ${ }^{(9)}$ The authors analyzed two main questions, namely the association between the welding job and PD and the association between manganese exposure and PD. The authors demonstrated that the pooled relative risks of the welding job to PD disease was 0.86 (95\% CI: $0.80-0.92$ ) and that of manganese exposure to PD was 0.76 (95\% CI: 0.41-1.42).
The authors concluded that both the welding job and manganese exposure were not related to an increased risk of PD.

Racette et al. ${ }^{(10)}$ compared the prevalence of Parkinsonism in welding-exposed workers to the reference group. The study utilized clinical assessment including the use of the Unified Parkinson's Disease Rating Motor Scale 3 (UPDRS3) to categorize the subjects into Parkinsonism (score $>15$ ), intermediate (score 614) and normal (score $<6$ ). The exposure assessment was performed using a questionnaire. The prevalence of Parkinsonism in the welding 
job was $15.6 \%$ and in the non-welding jobs $0 \%$. The study concluded that welding-exposed workers had a high prevalence of Parkinsonism compared to the non-exposed workers.

In another article, Racette et al.(11) assessed the progression of Parkinsonism in the manganese-exposed welders in three worksites. They measured the clinical assessment of 886 workers using UPDRS3 questionnaire and clinical evaluation while the exposure assessment was measured by questionnaire. The authors followedup the patients, with a mean follow up of 4.2 years and revealed that in all examined workers, there was a change of $0.24(0.10-0.38)$ in UPDRS3 score. The study concluded that the progression of Parkinsonism increased with increased cumulative manganese exposure.

Up to now, there has been a controversy on whether welding-exposed workers are associated with PD. Some studies supported and other studies refuted the association. Park pointed out that one of the factors that induced these conflicting findings were the pitfalls in various methodological issues in the studies, including a healthy worker effect bias, statistical modeling and the use of litigation studies. In addition, a number of studies also did not carefully consider confounder factors in manganese work such as the exposure to carbon-monoxide, aluminum and heat stress. ${ }^{(6)}$

Couper first reported the association between manganese exposure and neurobehavioral symptoms in 1873. ${ }^{(12)}$ The report was the first to mention the toxicity of manganese in humans, which is now known as manganism. Manganism is a neurobehavioral syndrome due to an excessive accumulation of manganese in the brain from manganese exposure. Manganism has clinical features resembling $\mathrm{PD}$, and therefore many physicians misdiagnose manganism as PD. In fact, manganism and PD are two different entities with different clinical and pathological manifestations. ${ }^{(13)}$ The distinguishing characteristics of manganism are the absence of resting tremor, the appearance of gait disorder as an initial symptom and the lack of response to L-dopa. Also, in contrast to PD, neuroimaging in patients with manganism does not reveal any degeneration of dopaminergic neurons in the substantia nigra and dopamine insufficiency in the striatum. ${ }^{(14)}$

Comparing the three selected articles, the study of Mortimer et al. ${ }^{(9)}$ is more relevant and appropriate for answering the clinical question. First, Mortimer used a meta-analytical method in scrutinizing relevant studies. The authors applied strict inclusion and exclusion criteria and excluded studies that potentially led to bias effects, lacked validity, and inadequate statistical method. The authors also calculated the heterogeneity of study effects to argue that the existing variation in the studies was due to chance.

Unlike Mortimer, Racette et al. ${ }^{(10)}$ supported the relationship between welding or manganese exposure and Parkinsonism. In their article, the authors showed an increased prevalence of Parkinsonism in welding-exposed workers compared to the reference population $(15 \%$ vs. $0 \%)$. However, Racette's study has some potential bias, mainly due to the use of the questionnairebased metric for exposure calculation. Recall bias might occur because the subjects might provide inadequate information when estimating the type, quantity and the duration of exposure. A selection bias might also occur because the authors utilized the reference group sample provided by the trade union without clear subject criteria.

In another article Racette et al. ${ }^{(11)}$ followed up the manganese-exposed workers to observe the progression of Parkinsonism. During a mean follow-up period of 4.2 years, the authors found that in the manganese-exposed workers there

Table 1. Search strategy using keywords

\begin{tabular}{llcl}
\hline \multicolumn{1}{c}{ Database } & Keyword & Hits & Filter \\
\hline PubMed & "Welding" OR "welder" AND "Parkinson" & 26 & Title/abstract \\
Cochrane Library & "Welding" OR "welder" AND "Parkinson" & 88 & Title/abstract \\
JSTOR & "Welding" OR "welder" AND "Parkinson" & 3 & Title/abstract \\
\hline
\end{tabular}


Table 2. Critical appraisal checklist for systematic review

\begin{tabular}{|c|c|c|c|}
\hline Article & \multicolumn{3}{|c|}{$\begin{array}{l}\text { Mortimer JA, et al. Association of welding and manganese exposure with Parkinson's disease } \\
- \text { review and meta-analysis. }{ }^{(9)}\end{array}$} \\
\hline Level & \multicolumn{3}{|c|}{1 (Systematic review of clinical trials, cohort, case-control studies) ${ }^{(7)}$} \\
\hline Questions & $\begin{array}{l}\text { Does the systematic review } \\
\text { address a focused question } \\
\text { (PICO) and use it to direct the } \\
\text { search and select articles for } \\
\text { inclusion? }\end{array}$ & Yes & $\begin{array}{l}\text { The authors analyzed the association } \\
\text { between welding and PD and the } \\
\text { association between manganese exposure } \\
\text { and PD. The authors applied the focused } \\
\text { questions to select the most relevant } \\
\text { articles. }\end{array}$ \\
\hline Find & $\begin{array}{l}\text { Did the research find all the } \\
\text { relevant evidence? }\end{array}$ & Yes & $\begin{array}{l}\text { The authors searched PubMed and } \\
\text { Cochrane databases, published reviews and } \\
\text { abstracts of scientific meetings. }\end{array}$ \\
\hline Appraise & $\begin{array}{l}\text { Have the studies been critically } \\
\text { appraised and was the overall } \\
\text { quality adequate? }\end{array}$ & Yes & $\begin{array}{l}\text { The authors indicated some appraisal } \\
\text { criteria for the focused questions, such as } \\
\text { types of exposure, outcomes, and number of } \\
\text { person-years followed up. }\end{array}$ \\
\hline Synthesize & $\begin{array}{l}\text { Have the results been synthesized } \\
\text { with appropriate summary tables } \\
\text { and plot? } \\
\text { Were the results similar between } \\
\text { studies? }\end{array}$ & Yes & $\begin{array}{l}\text { The authors listed the details of each study } \\
\text { in the appropriate tables and plot/pooled } \\
\text { relative risk. } \\
\text { The results of the studies were similar, in } \\
\text { that the relative risk (RR) for both welding } \\
\text { and manganese exposure to PD were less } \\
\text { than } 1 \text {. }\end{array}$ \\
\hline Result & $\begin{array}{l}\text { What measure was used, how } \\
\text { large was the effect (could it have } \\
\text { been due to chance?) }\end{array}$ & Uncertain & $\begin{array}{l}\text { The RR between welding and PD was } 0.86 \\
(0.80-0.92) \text { and between manganese } \\
\text { exposure and PD } 0.76(0.41-1.42) \text {. } \\
\text { The association between welding and PD } \\
\text { lacked heterogeneity, indicating that the } \\
\text { different results of the reviewed studies } \\
\text { were due to chance. }\end{array}$ \\
\hline
\end{tabular}

was a progression of Parkinsonism evidenced by a 0.32 (SD 2.1) change in UPDRS3 score. However, this article also has potential bias, such as information, recall and selection bias, mainly due to the use of questionnaire findings that were converted into weighted exposure years.

In relation to the patient concerned in this case illustration, there are some reasons to argue that his PD is not related to his job. First, aging - not manganese exposure - is the largest contributing factor for PD; PD affects $1 \%$ of the population above 60 years and $5 \%$ of the population over 85 years. Around $5 \%$ of PD, however, occurs at the age below 60 years and this is associated with mutations in a number of genes such as PINK-1, Parkin, DJ-1 and alphanuclein. ${ }^{(15)}$ Second, PD is a multifactorial disease, where various risk factors may play a role in the occurrence of the disease. The patient has a number of risk factors, such as diabetes and hypertension, which may play a role in the onset of his PD. Third, based on current and relevant evidence-based medicine publications available, including meta-analytical studies, no increased PD risk is observed in welders or welding-exposed workers. ${ }^{(9)}$ 
Table 3. Critical appraisal checklist for a cross-sectional study

\begin{tabular}{|c|c|c|}
\hline Article & \multicolumn{2}{|c|}{$\begin{array}{l}\text { Racette BA, et all. Increased risk of Parkinsonism with welding } \\
\text { exposure. }\end{array}$} \\
\hline Level & \multicolumn{2}{|c|}{ Level 2 c (Case-control study) ${ }^{(8)}$} \\
\hline $\begin{array}{l}\text { Did the study address a clearly } \\
\text { focused question? }\end{array}$ & Yes & $\begin{array}{l}\text { To determine the prevalence and phenotype of } \\
\text { Parkinsonism in shipyard and fabrication welders and } \\
\text { compare these with non-exposure subjects comprising } \\
\text { PD patients from Movement Disorders Center, } \\
\text { Washington. }\end{array}$ \\
\hline $\begin{array}{l}\text { Is the research method (study } \\
\text { design) appropriate for answering } \\
\text { clinical questions? }\end{array}$ & Yes & $\begin{array}{l}\text { The study type (cross-sectional and nested case- } \\
\text { control) is appropriate for the prevalence estimation. }\end{array}$ \\
\hline $\begin{array}{l}\text { Is the method of selection of the } \\
\text { subjects (employees, team, } \\
\text { division, organization) clearly } \\
\text { described? }\end{array}$ & Uncertain & $\begin{array}{l}\text { The authors did not mention the reason for the } \\
\text { recruitment from the places. }\end{array}$ \\
\hline $\begin{array}{l}\text { Could the way the sample was } \\
\text { obtained introduce (selection) bias? }\end{array}$ & Yes & $\begin{array}{l}\text { In the study subjects, the authors took the list of } \\
\text { welders and contacted them for participation. } \\
\text { In the reference group 1, the subjects were recruited by } \\
\text { the local trade union and the authors were not given } \\
\text { the list of the workers. } \\
\text { In the reference group 2, the subjects were taken from } \\
\text { the clinical database of newly diagnosed untreated PD } \\
\text { at Movement Disorders Center, without any subject } \\
\text { selection criteria. }\end{array}$ \\
\hline $\begin{array}{l}\text { Was the sample of subjects } \\
\text { representative with regard to the } \\
\text { population to which the findings } \\
\text { will be referred to? }\end{array}$ & $\begin{array}{l}\text { Yes for the } \\
\text { study group } \\
\text { but not for } \\
\text { the } \\
\text { reference } \\
\text { groups }\end{array}$ & $\begin{array}{l}\text { In the study group, the subjects represented the } \\
\text { population to which the finding referred. In the } \\
\text { reference groups } 1 \text { and } 2 \text {, the recruited samples did not } \\
\text { represent the reference population. }\end{array}$ \\
\hline $\begin{array}{l}\text { Was the sample size based on pre- } \\
\text { study considerations of statistical } \\
\text { power? }\end{array}$ & No & No predetermined sample size. \\
\hline $\begin{array}{l}\text { Was a satisfactory response rate } \\
\text { achieved? }\end{array}$ & Yes & $\begin{array}{l}811 \text { workers out of } 1,612 \text { welding-exposure workers } \\
(50.3 \%) \text { agreed to participate. }\end{array}$ \\
\hline $\begin{array}{l}\text { Were the measurements } \\
\text { (questionnaires) likely to be valid } \\
\text { and reliable? }\end{array}$ & $\begin{array}{l}\text { For the } \\
\text { clinical } \\
\text { diagnosis } \\
\text { they were } \\
\text { valid and } \\
\text { reliable but } \\
\text { for the } \\
\text { exposure } \\
\text { assessment, } \\
\text { they lacked } \\
\text { validity and } \\
\text { reliability. }\end{array}$ & $\begin{array}{l}\text { Clinical diagnosis of Parkinsonism was based on a } \\
\text { neurological examination that included UPDRS3 } \\
\text { questionnairre. The clinical assessment is considered } \\
\text { valid and reliable. } \\
\text { Exposure assessment utilized welding exposure } \\
\text { questionnaire. Based on the questionnaire, weighted } \\
\text { exposure-years was calculated for each participant. }\end{array}$ \\
\hline
\end{tabular}


Table 4. Critical appraisal checklist for a prospective cohort study

\begin{tabular}{|c|c|c|}
\hline Article & \multicolumn{2}{|c|}{$\begin{array}{l}\text { Racette BA, et all. Dose-dependent progression of } \\
\text { Parkinsonism in manganese-exposed welders. }\end{array}$} \\
\hline Level & \multicolumn{2}{|c|}{ Prospective cohort $(2 \mathrm{~b})^{(8)}$} \\
\hline \multicolumn{3}{|l|}{ Are the results of the study valid? } \\
\hline $\begin{array}{l}\text { Was the defined representative samples of } \\
\text { patients assembled at a common (usually } \\
\text { early) point in the course of their diseases? }\end{array}$ & Yes & $\begin{array}{l}\text { Baseline examination on the study subjects was } \\
\text { conducted from January } 2006 \text { to September } \\
2013 \text {. }\end{array}$ \\
\hline $\begin{array}{l}\text { Was patient follow up sufficiently long } \\
\text { and complete? }\end{array}$ & Yes & $\begin{array}{l}\text { Each subject had a different period or number } \\
\text { of follow up. } 61 \% \text { had } 1 \text { follow-up, } 26 \% \text { had } 2 \\
\text { follow-ups, } 12 \% \text { had } 3 \text { follow-ups and } 1 \% \text { had } \\
4-5 \text { follow-ups. Mean time period between } \\
\text { baseline and any follow-up was } 3.9(1.8) \text { years. }\end{array}$ \\
\hline $\begin{array}{l}\text { Were outcomes criteria either objective or } \\
\text { applied blindly? }\end{array}$ & Yes & $\begin{array}{l}\text { The primary outcomes were the rates of } \\
\text { changes of UPDRS } 3 \text { score. The secondary } \\
\text { outcomes were the annual rates of changes of } \\
\text { UPDRS } 3 \text { sub-score. } \\
\text { The exposure assessment was blinded to the } \\
\text { neurologists who examined the subjects. }\end{array}$ \\
\hline $\begin{array}{l}\text { If subgroups with different prognosis are } \\
\text { identified, did an adjustment for important } \\
\text { prognostic factors take place? }\end{array}$ & Yes & $\begin{array}{l}\text { The authors adjusted the prognostic factors; e.g. } \\
\text { duration of exposure to baseline examination } \\
\text { was divided into }<5 \text { years and } \pm 5 \text { years. }\end{array}$ \\
\hline \multicolumn{3}{|l|}{ What are the results? } \\
\hline How likely are the outcomes over time? & Yes & $\begin{array}{l}\text { The authors provided the estimation of } \\
\text { expected additional increase of UPDRS } 3 \text { score } \\
\text { over a } 10 \text {-year time period }\end{array}$ \\
\hline How precise are the prognostic estimates? & Uncertain & $\begin{array}{l}\text { The precision of prognostic value can be based } \\
\text { on the confidence interval. The confidence } \\
\text { intervals of findings were mixed, some of them } \\
\text { were narrow and the rest were wide. }\end{array}$ \\
\hline $\begin{array}{l}\text { Can I apply this valid, important evidence } \\
\text { about prognosis to my patient? }\end{array}$ & No & $\begin{array}{l}\text { The study subjects were from the shipyard and } \\
\text { fabrication unit while our patient was from a } \\
\text { gas and petroleum company. } \\
\text { The race also matters, since the study subjects } \\
\text { were non-Hispanic Caucasian and our patient } \\
\text { was Arabic. } \\
\text { Our patient had consumed PD medication and } \\
\text { therefore the estimation of PD deterioration } \\
\text { using a time-based estimation cannot be } \\
\text { applied. }\end{array}$ \\
\hline
\end{tabular}

\section{LEARNING POINTS}

Based on the selected evidence-based resources, it is concluded that: (i) Parkinson' disease is not related to the welding job; (ii) The welding job, however, may produce clinical symptoms and signs resembling PD, known as manganism. 


\section{CONFLICTS OF INTEREST}

None.

\section{ACKNOWLEDGEMENTS}

We would like to thank the staff of the Department of Community Medicine, Universitas Indonesia for the support for this publication.

\section{CONTRIBUTORS}

IM contributed to conceptualization and methodology. IM and MM contributed to preparing and writing the original draft. MM contributed to supervision. IM contributed to review and editing. All authors have read and approved the final manuscript.

\section{REFERENCES}

1. Rocca WA. The burden of Parkinson's disease: a worldwide perspective. Lancet Neurol 2018;17: 928-9. doi: 10.1016/S1474-4422(18)30355-7.

2. Oertel WH. Recent advances in treating Parkinson's disease. F1000Res 2017;6:260. doi: 10.12688/f1000research.10100.1.

3. DeMaagd G, Philip A. Parkionson's disease and its management. PT 2015;40:504-32.

4. Ascherio A, Schwarzschild MA. The epidemiology of Parkinson's disease: risk factors and prevention. Lancet Neurol 2016;15:1257-72. DOI: https://doi.org/10.1016/S1474-4422(16) 30230-7.

5. Xu Y, Yang J, Shang H. Meta-analysis of risk factors for Parkinson's disease dementia. Transl Neurodegener 2016;5:1-8.
6. Park RM. Neurobehavioral deficits and Parkinsonism in occupations with manganese exposure: a review of methodological issues in the epidemiological literature. Saf Health Work 2013;4:123-35.

7. Glasziou PP, Mar CD, Salisbury J. Evidence-Based Practice Workbook. 2nd ed. London: Blackwell Publishing - BMJ Books; 2007.

8. Oxford Centre for Evidence Based Medicine (CEBM). Critical Appraisal Tools. Oxford;2019.

9. Mortimer JA, Borenstein AR, Nelson LM. Associations of welding and manganese exposure with Parkinson's disease: review and meta-analysis. Neurology 2012;79:1174-80.

10. Racette BA, Criswell SR, Lundin JI, et al. Increased risk of Parkinsonism with welding exposure. Neurotoxicology 2012;33:1356-61.

11. Racette BA, Nielsen SS, Criswell SR, et al. Dosedependent progression of Parkinsonism in manganese-exposed welders. Neurology 2017;88: 344-51.

12. Couper J. On the effects of black oxide of manganese when inhaled in the lungs. Br Ann Med Pharmacol 1873;1:41-2. Cited by: Blanc PD. The early history of manganese and the recognition of its neurotoxicity, 1837-1936. Neurotoxicology 2018;64:5-11. doi: 10.1016/ j.neuro.2017.04.006

13. Kwakye GF, Paoliello MMB, Mukhopadhyay S, et al. Manganese-induced Parkinsonism and Parkinson's disease: shared and distinguishable features. Int J Environ Res Public Health 2015; 12: 7519-40.

14. Guilarte TR. Manganese and Parkinson's disease: a critical review and new findings. Environ Health Perspect 2010;118:1071-81.

15. Reeve A, Simcox E, Turnbull D. Ageing and Parkinson's disease: why is advancing age the biggest risk factor? Ageing Res Rev 2014;14:19 30 . 